\title{
PREDICATES OF STATE DENOTING MENTAL CONDITION OF MAN
}

\section{Shutova M. O., Mudrynych S. Yu.}

\section{INTRODUCTION}

The question of the classification of verbal meanings has long attracted the attention of representatives of different linguistic schools. A number of classifications were created, based on different grounds, but no clear distribution and description of verbal meanings could be made by any scientist. In developing this problem, linguists have encountered a great number of difficulties due to the fact that "the verb is the most complex and capacious grammatical category"1. All attempts to solve this question on a formal and grammatical basis were doomed to failure because, by intuitively distinguishing classes of verbs, the researchers did not attempt to give them detailed classification features.

The topicality of research is specified of the complex study of lexicalsemantic groups of predicates of state and opens new perspectives for the exposure of semantic word-building features of the predicates of state, so for cognition of their role in the linguistic picture of the world that answers the tasks of the system and functional approach to the language phenomena, helps to determine directions of state on denotation envelopment of the lexical system on the whole.

The aim of the investigation consists in the analysis of lexical-semantic properties of predicates of state denoting mental condition of man in the different contexts of functioning. The set purpose will be realized through the concluding of such definite tasks: to consider a question about semantic classification of predicates of state in the English language; to define the classification signs of predicates of state; to make general semantic classification of predicates of state in the English; to analyze lexicalsemantic properties of predicates of state denoting mental condition in different contexts of functioning.

\section{Methodol ogy}

The success of scientific intelligence largely depends on the consistent adherence and clear application of scientific principles. Scientific principles

1 Виноградов В.В. Об омонимии и смежных явлениях. Избранные труды. Исследования по русской грамматике. Москва, 1975. С. 237. 
are considered to be fundamental in solving a scientific problem, a way of organizing knowledge that provides an organic link between the various elements of knowledge within a coherent theoretical system. They are of a regulatory nature, that is, the researcher must comply with them, otherwise scientific research ceases to be scientific. True science arises only when specific scientific methods are formed and systematically used - a set of ways and means of empirical and theoretical study of objects and phenomena of reality.

Through scientific methods, they acquire knowledge that can be tested, stored and transmitted. The fate of a scientific discovery depends to a large extent on the right method, and therefore, not only the result of the research, but also the path that leads to it, must always be properly chosen. The method determines the approach to the research object, the relationship between the subject and the research object, the method of construction of scientific knowledge, the general orientation and nature of the study ${ }^{2}$.

The complex of methods of linguistic analysis is used for decision of set tasks in the investigation. The descriptive method allows choosing research units and realizing their classification and interpretation. It is used for determining the state, conducting an inventory of the words of the semantics of the state and explaining the peculiarities of their structure and functioning at a certain stage of language development, in synchrony, as well as to establish the part-language potential of the words of the status category and to carry out their classification and interpretation. Using the techniques of internal interpretation on the basis of comparison and juxtaposition of linguistic units, their differential features are established, and on the basis of the commonality and differences of the unit are combined into different paradigmatic groups.

The structural method is aimed at identifying features of linguistic representation of predicates, processes of interaction of semantic and formalsyntactic. Transformational method and method of synonymous substances are used at semantic analysis and classification of lexical-semantic groups of predicates of state. The construction of the formulas of interpretation required in the selection of lexico-semantic groups of predicates of state, allowed to fully reflect the meaningful content of the predicates of state. The methodological basis of the research is the scientific works in the field of English linguistics.

${ }^{2}$ Степанов Ю.С. Методы и принципы современной лингвистики : монография. Москва : Едиториал УРСС, 2005. 312 с. 


\section{Semantic signs of predicates of state}

Topical for modern linguistics is a comprehensive study of individual lexical semantic groups (hereinafter - LSG). Study of LSG from different sides leads to the disclosure of the general processes of vocabulary development, that is, for linguistics is not indifferent to the way that in each particular language is given a subject-semantic area, what signs of objects are displayed in separate names, and, therefore, characterize different members of the same semantic group ${ }^{3}$.

Word classes can be characterized depending on which components, whether formal or semantic, are common to words in a given class. From this point of view, there are three types of word classes: formal, formalsemantic and semantic ${ }^{4}$.

The most important from the point of view of the lexical system is the type of word classes being the last of them, or the lexical-semantic groups (LSG). The lexical-semantic group is the largest word organization in terms of its members, which is united by a common (basic) semantic component ${ }^{5}$.

Linguists identify the predicates of the state with the value of the mental and physiological state of man and words with the value of the state of nature, environment (Zheltov, 2001, Lakoff, 1987; Langacker, 1997). Also they emphasize that there is a relationship between the value of the state predicates and their syntactic compatibility with belonging to one or another category.

As you know, state verbs are not used in the Continuous form. B. Comrie argues that the use or non-use in progressives is semantically predetermined: although not all languages "have a long-lasting aspect, there is an arbitrary choice of verbs to indicate the condition in different languages" $"$. According to D.R. Doughty, stative verbs in English can be categorized into four semantic groups: emotional verbs, possessive verbs, cognitive verbs (verbs expressing cognition and mental processes) and verbs that denote existence. Among the cognitive verbs-states D.R. Doughty identifies: believe, desire, forget, imagine, know, mean, realize, recognize, remember, suppose, think, guess, presuppose, recall, regard, suspect, doubt, understand, impress ${ }^{7}$.

3 Іваницька Н.Б. Функціонально-семантична класифікація абсолютивних дієслів в українській та англійській мовах : монографія. Київ : КНТЕУ, 2004. С. 48.

Апресян Ю.Д. Синтаксическая обусловленность значений. Русский язык в школе. 1967. № 6. С. 6.

5 Желтов Ю.О. О лексико-семантических особенностях категории состояния. Вестник Башкирск. ун-та. 2001. № 3. С. 23.

${ }^{6}$ Comrie B. Aspect. Cambridge University Press, 1985. P. 97.

${ }^{7}$ Dowty D.R. Temporary Restrictive Adjectives. Syntax and Semantics. New York, 1998. P. 34. 
R. Quirk and S. Greenbaum, in their own aspectual classification of verbs, distinguish intellectual states: believe, know, realize, think, understand ${ }^{8}$. It is intellectual states that make up a large group of state verbs that do not allow their use in the Continuous form. E.M. Gordon and I.P. Krylova divide English verbs by semantics into action-defining words, the term "action" has the meaning of: 1) activity - to walk, to speak, to play, to study; 2) process - to sleep, to wait, to live; 3 ) states - to be, to like, to know; 4) attitude - to consist, to resemble, to lack.

According to Continuous form, scientists divide them into two groups: action verbs and state verbs. Action verbs can be used in Continuous form, and state verbs cannot be used in Continuous form. The difference between action verbs and state verbs is fundamental in English grammar. Grammarians identify the most common state verbs: verbs that reflect physical sensations: to hear, to see; verbs that express feelings: to adore, to detest, to dislike; verbs that express desire: to desire, to want, to wish; verbs that reflect thought processes: to admire (to be of a high opinion), to appreciate, to understand; relative verbs: to apply, to be, to belong, to concern, to contain, to depend, to depend, to deserve, to some other verbs: to agree, to allow, to appear (= to seem), to astonish, to claim, to consent ${ }^{9}$.

Before defining the lexical-semantic bits of the words of the semantic of state, let's try to outline the semantic features that will allow us to divide the words into groups. L.V. Vasilyev believes that the work on studying the semantic system of any language is most appropriate to begin with a comprehensive description of individual semantic classes ${ }^{10}$.

E.V. Kuznetsova insists on a comprehensive approach, because the place of a word in the lexical system of language is determined by both external factors (correlation with reality and thinking) and internal (syntagmatic and paradigmatic connections with other words $)^{11}$.

For the state verbs, the defining sema is "to be in some state". For proper and complete selection of LSG you need to find all those categorical-lexical semas that combine the lexemes into one semantic class.

According to the results of the study of the classification features of verbal state predicates, we distinguish the following semantic signs of predicates of state in English:

\footnotetext{
${ }^{8}$ Quirk R. A Student's Grammar of the English Language. Longman Press, 1991. P. 386.

${ }^{9}$ Gordon E.M. A Grammar of Present-Day English. Москва : Высшая школа, 1980. P. 253.

10 Васильев Л.М. Предикаты состояния в русском языке. Исследования по семантике (Семантика языка и речи). Уфа : Изд-во Башкирск. гос. ун-та, 1991. C. $32-49$.

11 Кузнецова Э.В. Части речи и лексико-семантические группы слов. Bonpocbl языкознания. 1975. № 5. С. 83.
} 
1. Time axis affiliation. A state, unlike actions and processes, is directly placed on the time axis, so it occurs at any point in the segments with which it is related.

2. Inactivity. The words of the semantic of state cannot be meaningful, they exist on their own and do not require any effort to support it.

3. Focus on the subject. If the subject is not directly manifested in the grammatical structure of the sentence, then its reading is not difficult. The state subject belongs to the type of passive subjects. Therefore, the course or maintenance of a state is entirely determined by the external to the subject by force, therefore the state exists by itself. The designation of the state refers primarily to persons, indicating their intrinsic, psychic properties, which cannot be observed directly or through their external manifestation s, for example: He is ashamed; We are happy. Internal states cannot be observed directly, so they can only be analyzed by their manifestations.

4. Static. In the semantics of state words, the idea of static equilibrium is expressed, in which nothing is created, changed, or moved, so the words of state semantics in any context keep the value of continuous flow relevant for a particular period of time.

The semantic characteristics of the state words include temporality and aspectuality, which allow them to be qualified and classified according to such indicators: dynamic/statistical, action, activity, state, event and others.

\section{Semantic characteristics of the state words}

Any human condition is a reflection of those phenomena or qualities of things that are perceived by the senses and consciousness. Therefore, the distribution of the words of the semantics of state into groups should represent the psychological conditionality of perception.

Different researchers place different criteria in the division of verbs into lexical-semantic classes. The following semantic features can be used as a basis for division: static/dynamic; duration/moment; controllability/ uncontrollability; agency/non-agency ${ }^{12}$.

Therefore, there are several variants of verb separation in English. The most common is the division of verbs by the aspect of static/dynamic into action verbs, denoting action, process, and state verbs, describing different mental and emotional states.

Traditionally, the following features are distinguished: the states do not have a phase structure; the states are "ongoing", long in time, if they are

12 Кузнецова Э.В. Части речи и лексико-семантические группы слов. Bonpocbl языкознания. 1975. № 5. С. 86. 
"viewed from the middle"13; states are unintentional, uncontrolled; states are immutable, homogeneous ${ }^{14}$. Each of the above points can be denied.

Although states do not have a phase structure, they can begin and end. The beginning of the state is receptive, the end is terminative, that is, the beginning and end of the state are dynamic.

The question How long...?; For how long...? indicates the duration, time length of the state. Duration theoretically implies state boundaries. State verbs belong to unbounded predicates: it is difficult to trace the end of mental states or feelings because they are uncontrollable. On the one hand, states are unintentional and uncontrollable.

State verbs do not indicate volitional acts. On the other hand, mental states are the result of previous mental acts, and therefore the unpredictability of the state as a result cannot be stated.

States are unchanged. B. Comrie compared run and know in terms of phase. In the sentence John knows where I live, all phases of the situation are the same, whatever the time interval, the situation remains the same. In the sentence John is running, phases are different and alternate alternately ${ }^{15}$.

However, not everyone agrees with this conclusion. E.V. Kuznetsova believes that the states are indeed signs, but only those that imply a preliminary process. Each state must be preceded by the process that triggers it. Knowledge is preceded by thinking, learning, understanding. The construction be + Adj (be married, be hard) can be considered a state, since there are processes of hardening, marrying ${ }^{16}$.

To is olate the lexical-semantic group of state verbs in the vocabulary of modern English literary language, it was decided to carry out the work by deductive method - from the whole volume of the morphological class of verbs to go to the subclass of state verbs. To distinguish LSG, a number of classification features have been developed that distinguish verbs from other semantic groups. The analysis of verbal vocabulary was based on the material of specific syntactic constructions, since the semantic class defines its features only in the composition of sentences.

The central semantic union of units is the lexical-semantic group. Lexical- semantic groups are a combination of meanings of words that denote specific concepts that differ in the degree of expression of quality, characteristics, actions, objects, phenomena. Lexical-semantic groups

${ }^{13}$ Там само. С. 50.

14 Желтов Ю.О. О лексико-семантических особенностях категории состояния. Вестник Башкирск. ун-та. 2001. № 3. С. 45.

${ }^{15}$ Comrie B. Aspect. Cambridge University Press, 1985. P. 96.

16 Кузнецова Э.В. Части речи и лексико-семантические группы слов. Bonpocbl языкознания. 1975. № 5. С. 83. 
combine synonymic word strings that express one concept, but on different sides, that is, different features, characteristics ${ }^{17}$.

Thus, in the first lexical-semantic group of verbs with the meaning of the human condition, we distinguish two subgroups of words: the designation of the physical condition of the person and the designation of the mental state of the person. In the second lexical-semantic group of verbs with the meaning of the state of nature, the environment is also leading to human perception. Here we distinguish such subgroups of verbs, where the state of nature is perceived by the organs of vision, at organs of hearing, at temperature sensations, at tactile sensations, at position and movement of the person in space, taste and olfactory sensations, at organic sensations, a state emotionally evaluated by the person, a state intellectually evaluated by a person.

First of all, consider the words with the value of the physical state of man, where you can distinguish the following subgroups of words:

- a verb with the meaning of a condition that occurs with pain and temperature sensations: to be cold, to be hot, to be ill, to sweaty, to be sick, to feel hot and others, for example: The night was bitterly cold but they didn't seem to feel cold (J. Hilton);

- the position of a person in space, movement, time in English is conveyed by verbs-conjunctions that form a compound noun phrase: to be comfortable, to be crowded, to be empty, to be early, to be in time, to be late, to be soft; as well as traffic condition: afoot, astir, afloat and others; space: afire, aflame, alive, asleep, awake, alone, apart, ahead and others.

- length in space in English is conveyed by verbs-conjunctions that form a compound noun phrase: to be deep, to be not deep, to be far, to be not far away, to be high, to be low, to be narrow, to be wide, astray, astride, askew, asquint and others, for example: I was high in the mountains (E. Hemingway); We were low the river, the singing ceased; the young moon hid behind a tree, and all was dark (J. Galsworthy); "Nonsense! I prefer astride (A. Christie);

- visual and auditory sensations: to hear, to notice, to see and others, for example: She heard his voice, which sounded dry and harsh (F. O'Connor); But Julia did not notice the film-stars, they went, she stayed (S. Maugham); You see this creature with her curbstone English: the English that will keep her in the gutter to the end of her days (B. Show);

- organic sensations in English are conveyed by verb-conjunctions that form a compound noun phrase: to be hard, to be haggard, to be hungry, to feel bad, to feel not well, to feel sick, to feel queer, to feel pain, to feel

17 Кузнецова Э.В. Части речи и лексико-семантические группы слов. Bonpocbl языкознания. 1975. № 5. С. 79. 
tickling, athirst and others, for example: And George was haggard (M. Spark); "Your Tod is hungry, and must be red" (A. Cronin).

The second is a group of verbs with the meaning of a person's mental state, depends on the external and internal influences on the organs of human perception. There are subgroups of state semantics with values:

- human emotional state: to be in calm, to be funny, to be gay, to be hungry, to be in love, to be in spirits, to be sad, to be terrified, to become unreasonable, to detest, to dislike, to hope, to hate, to like, to love and others. For example: But this April in 1844 was unusually warm and the miners after being on strike almost three weeks were still in high spirits (G. Gordon); But here, at Shangri-ha, all of us were in deep calm (A. Christie); Jan Cloot became unreasonable in tone (M. Spark); Nye saw that she wanted to leave, but was afraid to admit it (A. Cronin); I'm not in love with her as I was in love with Isabel (S. Maugham);

- willful state of the person: to be busy, to be free, to be lazy, to desire, to force, to feel bad/unhappy, to forbid, to require, to want, to wish and others, for example: But all the moment he was too busy planning the day (A. Cronin); God forbid that he should know anything about the forces of Nature! God forbid that he should admit for a moment that there are such things (J. Galsworthy);

- the moral state of the person: aghast, ashamed, afraid, agape, agog, to assume, to believe, to be envious, to be sorry, it's a sin (to), it 's useless, to respect and others, for example: But if I was not personally concerned I should be sorry at the waste (J. Hilton); "You don't seem in the least ashamed"'(F. O'Connor); He put his head back gently as if he was afraid it would crack (F. O'Connor);

- the intellectual state of a person: aware, assure, assume, to admire, it is known, it is correct, it is true, it is reasonable, in vain, it is unscrupulously, it is indifferent, it is efficient, it is passive, how interesting and more, for example: He was well aware of the need of the local paper (A. Cronin); "It is true there's no one to see. He's quite alone"(J. Hilton); Even when my husband was alive I was always too busy with my films or my baby, it is known (F. O'Connor);

- with a modal tone: it's advisable, it is necessarily, it is necessary, it's enough, it is impossible, it is possible, it is well worth, it is well worthless, it is time and others. Modal significance has many shades: possibilities, impossibilities, obligations, necessities, needs, assumptions, for example: You may or may not be aware that shortly before she died Miss Arundell wrote to me (A. Christie); "Is it possible to have wine with the meals?" Iasked her (E. Hemingway); Is it necessary to have a barber before breakfast? (J. Hilton). 
Human perception also underlies the classification of the words of the semantics of the state with the meaning of the state of nature. Depending on which organs and under what circumstances the phenomenon is perceived, we distinguish the following subgroups of words:

- organs of vision: aglow, ablaze, alight, it is bright, it is bare, it is black, it is crowded, it is clean, it is clear, it is dirty, it is dark, it is empty, it is green, it is light, it is misty (foggy), it is snowy, it is white and others, for example: The winter passed into spring, and the gardens on the Riviera were ablaze with colour (S. Maugham); At the bottom of the steps, on one side, grew a large bush and it was alight with fireflies (S. Maugham); It was clear in the afternoon (J. Galsworthy);

- hearing: it is heard, it is noisy, it is stiffly, it is still, it is tranquil, it is windy and others, for example: The plain was spread before her; it was tranquil and serene in the morning light (L. Voynich); The air in the Yard Seam was hot and still (S. Lewis); There were numbers of them walking in the cool, after the day's heat, it was noisy and the air was alive with the sound of voices, murmuring secrets (J. Galsworthy);

- temperature sensation: it is cold, it is coolly, it is frosty, it is hot, it is warm and others, for example: It's too hot to go for a bike ride (M. Spark); It was cold in a daytime (M. Spark); The winter passed into spring and it was warm in the gardens on the Riviera (S. Maugham);

- tactile sensations: it is damp, it is dry, it is dusty, it is slippery and others, for example: The morning was dry and clear (F. O'Connor);

- taste and olfactory sensations: it is bitter, it is balmy, it is smell, it is sour, it is sweet, to smell, it is tasty, to taste and others, for example: The night was sweet, the pavements were dry, birds singing in the gardens, the air was soft and cool (A. Cronin); The air was balmy, not too much heat in the sun (J. Galsworthy); The air smelt of decay and stagnation (G. Parker);

- a state emotionally assessed by person: it is beautifully, it is blissfully, it is disgustingly, it is excellently, it is nice, it is pleasant, it is perfect, it is refined, it is sad, it is sultry, it is terrible, it is wonderfully and others, for example: The night was sultry and Kitty sat at the window looking at the fantastic roofs (M. Spark); The sun of the early autumn was pleasant, and if at daybreak was cold, the warmth later was very grateful (J. Hilton).

Thus, considering different views on the classification of the predicates of state in English, we can conclude that the central semantic association of units is the lexical-semantic group, and the main semantic signs of the predicates of state in English are belonging to the time axis, inactivity, inactivity subject of status, static, temporal and aspectual. 


\section{Classification of words denoting mental state}

The main criterion for the distribution of words by lexical-semantic groups is human perception. In the lexical-semantic group of words with the meaning of the human condition, we distinguish two subgroups of words: the designation of the physical condition of the person and the designation of the mental state of the person. In the lexical-semantic group of words to indicate the mental state of a person can be distinguished the following subgroups of words: emotional state of the person, volitional state of man, moral state of man, intellectual state of man.

Careful study of the classification of verbs within the individual semantic categories, which denote the physiological and psychologicalstates, gives an opportunity to adequately reconstruct the imaginary picture of the world of emotions and psychophysiological states that denote these verbs.

For the selection of LSG predicates of mental state of man verbal vocabulary of modern English literary language was subjected to analysis from the standpoint of the above criteria. The material of the study was the verbal vocabulary of Oxford English Dictionary (2010). Questions of any classification of lexemes in semantic terms are based on a deep understanding of the meaning of each word. Only a complete elucidation of the semantics of the verbs makes it possible to identify the seven of them, to correlate these tokens with a number of similar ones.

The semantic structure of a verb group is related to the transitivity and intransitiveness of the verb and is determined by the appropriateness of the lexical meaning of the verb to the subject or object. All the verbs in this group are divided into subgroups by the presence of the lexical-semantic variant of the state in the substantive structure: first, it is the verb, in the substantive structure of which there is a lexical-semantic variant of the state, for example: to matter v. - to be important, especially to be important to you, or to have an effect on what happens, for example: "No matter where you get a boat, it will be the same”, Burke said to Nisus (M. Spark), secondly, it is a verb in which the lexical-semantic variant of the condition is manifested through nouns having the same root morpheme, for example: to regret $\mathrm{v}$. - to feel sorry for something you have done and wish you have not done it, for example: "I regret about the Macpherson and the others", Nisus said to them (M. Spark); I was seized with regret to the brim (M. Spark); third, it is verbs in which the lexical-semantic variant of the condition is manifested through synonyms, for example: forgive $\mathrm{v}$. - to decide not to blame someone or to be angry with them, although they have done something wrong, for example: If they mention the American girl that took the pills in your flat, say you forgive her (M. Spark); and fourth, it is a verb in which the lexical-semantic variant of the condition is manifested through suffixes of the same root morpheme, for example: to prevent $\mathrm{v}$. - to do 
something, to prevent it from happening, prevention $\mathrm{n}$. - in the act of preventing something or the actions that you take ordering to prevent something, for example: She clenched her hands in ordering to prevent herself from telling him to hold his silly tongue (S. Maugham).

In this study, the meaning of each verb is determined by its interpretation in the Oxford English Dictionary and has been repeatedly tested on the material of specific syntactic structures. In the detailed description of the semantics of predicates of the mental state of a person, some commonality of meanings of individual tokens became noticeable. This made it possible to group them into closer groups with identical or very close semantic relations. Some verbs thus remained outside the selected subgroup because they exhibited individual semantic relations, with no analogues among the other units.

The selected semantic group has the following tokens: to be in calm, to be funny, to be gay, to be glad, to be in love, to be in spirits, to be sad, to be terrified, to become unreasonable, to detest, to dislike, to hope, to hate, to like, to love, to be busy, to be free, to be lazy, to desire, to force, to feel bad/unhappy, to forbid, to require, to want, to wish, to assume, to believe, to be envious, to be sorry, it's a sin (to), it's useless, to respect, to admire, it is known, it is correct, it is true, it is reasonable, in vain, it is unscrupulously, it is indifferent, it is efficient, it is passive, it's advisable, it is necessarily, it is necessary, it's enough, it is impossible, it is possible, it is well worth, it is well worthless, it is time, to desire, to want, to wish, to admire (to be of a high opinion), to appreciate, to believe (= to consider), to consider (= to regard), to doubt, to expect (= to suppose), to feel (= to consider), to imagine, to know, to perceive, to presume, to recall, to recognize, to recollect, to regard, to remember, to suppose, to think (= to consider), to trust, to understand, to apply, to be, to belong, to concern, to contain, to depend, to deserve, to differ, to fit, to have, to hold (= to contain), to involve, to lack, to matter, to need, to owe, to own, to possess, to remain, to require, to resemble, to result, to signify, to suffice, to exist, to agree, to allow, to appear (= to seem), to astonish, to claim, to consent, to displease, to envy, to fail to do, to feel (intr.), to find, to forbid, to forgive, to intend, to interest, to keep doing, to manage to do, to mean, to object, to please, to prefer, to prevent, to puzzle, to realize, to refuse, to remind, to satisfy, to seem, to smell (intr.), to sound (intr.), to succeed, to suit, to surprise, to taste (intr.), to tend, to value, to weigh, to assume, to cost, to regret, to resemble.

But a considerable volume (141 units) and a wide range of semantics raised the question of further detailed classification of the predicates of the condition to denote the mental state of the person. It is obvious that in addition to the "be in any state" archives, the semantics of LSG can be 
distinguished by a number of differentiated differential features of a more specific meaning.

These semas second-tier verb identifications allow us to single out smaller groups within LSG that integrate verbs that are close in semantics. Using a set of dichotomous semes such as "state positive - state negative", "positive attitude - negative attitude", "individual semantics - general semantics", etc., which act as differentiating signs, we can distinguish the following semantic subgroups:

1) verbs that mean positive state - to be in (a state of) bliss, to enjoy oneself, to be glad:

2) verbs denoting negative state - to be disturbed, to be capricious, to grieve (to grieve), to get lost, to grieve, to be nervous), to feel awkward, to feel melancholy, to be bored, to sorrow, to despond, to be afflicted, to be cunning;

3) verbs denoting positive attitude - to revere (to be proud), to feel sorry (for) (to pity), to console oneself (with) (to be comforted);

4) verbs meaning negative attitude - to fear, to be displeased (with), to be displeased (with), to bear malice, to pay no regard to (to neglect), to be indignant, to be angry (with), to feel (to be) ashamed (of) (to be ashamed);

5) verbs meaning highly specialized mental states (having individual semantics) - to hesitate, to be astonished, to doubt, to be agitated, to wait (for, till, until);

\section{CONCLUSIONS}

Thus, using a set of dichotomous semes such as "positive state - negative state", "positive relation - negative relation", "individual semantics general semantics", which act as differentiating signs, the following semantic subgroups were distinguished:verbs meaning positive status; verbs meaning negative; verbs meaning positive attitude; verbs meaning negative attitude; verbs meaning highly specialized mental states.

The main result of the research work is to determine the classification features of the predicates of state, the description of the general semantic classification of the predicates of state in modern English literary language, which have not received, to date, a thorough coverage in linguistic literature. The conduct of the study has allowed to draw a number of theoretical conclusions that are relevant for solving topical is sues of linguistics.

Being in the system of semantic functions, the philosophical category of the state reflects a real-world picture of the objective world. This semantic category has a number of classification features, distinguished at the logical and semantic level, which allow with sufficient accuracy to distinguish it from similar categories. 
The semantic category of the state is expressed in the system of verbal meanings. The scientific substantiation of the state in the system of values of verbal predicates is based on a logical-semantic basis. However, the classification of verbal meanings has its own peculiarities.

The main indicator of the verb's belonging to the lexico-semantic group of the state is the presence in its meaning of the basic archives "to be in some state". However, the diversity of verbal meanings within the already allocated LSG determines the need to reduce them to more detailed semantic subgroups. This operation is performed in the second stage of identification of verbal meanings using seven higher levels of identification, such as "state positive - state negative", "positive attitude - negative attitude", "individual semantics - general semantics". Relations between semantic subgroups is a hierarchically organized system that covers all the LSG states.

\section{SUMMARY}

The article is the attempt of exposure of dictionary limit of predicates of state; the semantic signs of predicates of state are outlined, classification of predicates is carried out on lexical-semantic groups. The results of generalization of material will assist in deepening understanding of the system of language, in particular on semantic level. The lexical-semantic properties of predicates of state on denotation of mental condition of man in the different contexts of functioning are under the consideration. A question about semantic classification of predicates of state in English is considered, the classification signs of predicates of state are determined, the attempt of general semantic classification of predicates of state is done. The analysis of lexical-semantic properties of predicates of state on denotation of mental condition in the different contexts of functioning was done. Except the meaning "be in any state" a number of differential signs of more concrete value were distinguished in lexical-semantic groups. These meanings of the second degree identification of verbs allowed to select less groups in the lexical-semantic groups. The classification signs of predicates of state were determined. The article is a step to deeper cognition of philosophical and language essence of predicates of state.

\section{REFERENCES}

1. Апресян Ю.Д. Синтаксическая обусловленность значений. Русский язык в школе. 1967. № 6. С. 3-6.

2. Васильев Л.М. Предикаты состояния в русском языке. Исследования по семантике (Семантика языка и речи). Уфа : Изд-во Башкирск. гос. ун-та, 1991. С. 32-49.

3. Виноградов В.В. Об омонимии и смежных явлениях. Избранные труды. Исследования по русской грамматике. Москва, 1975. 318 с. 
4. Желтов Ю.О. О лексико-семантических особенностях категории состояния. Вестник Башкирск. ун-та. 2001. № 3.57 с.

5. Іваницька Н.Б. Функціонально-семантична класифікація абсолютивних дієслів в українській та англійській мовах : монографія. Київ : КНТЕУ, 2004. 193 с.

6. Кузнецова Э.В. Части речи и лексико-семантические группы слов. Вопросы языкознания. 1975. № 5. С. 78-89.

7. Степанов Ю.С. Методы и принципы современной лингвистики : монография. Москва : Едиториал УРСС, 2005. 312 с.

8. Comrie B. Aspect. Cambridge University Press, 1985. 248 p.

9. Cuyckens H., Dirven R. Cognitive Approaches to Lexical Semantics. Berlin, New York : Mouton de Gruyter, 2003.499 p.

10. Dowty D.R. Temporary Restrictive Adjectives. Syntax and Semantics. New York, 1998. 295 p.

11. Gordon E.M. A Grammar of Present-Day English. Москва : Высшая школа, 1980. 335 c.

12. Lakoff G. Women, fire and dangerous things: What categories reveal about the mind. Chicago : The University of Chicago Press, 1987. 614 p.

13. Langacker R. Constituency, Construal, and Subjectivity. Cognitive Linguistics. Berlin; New York : Mouton de Gruyter, 1997. Vol. 8 (1). P. 1-32.

14. Quirk R. A Student's Grammar of the English Language. Longman Press, 1991. 490 p.

\title{
Information about the authors:
} Shutova M. O., Doctor of Philology, Head of Department of English Language and Translation of the Faculty of Oriental Studies

Kyiv National Linguistic University 73, Velyka Vasylkivska Str., Kyiv, 03150, Ukraine

\author{
Mudrynych S. Yu., \\ Ph.D. (Linguistics), \\ Associate professor of Department of English Language and Translation \\ of the Faculty of Oriental Studies \\ Kyiv National Linguistic University \\ 73, Velyka Vasylkivska Str., Kyiv, 03150, Ukraine
}

